\title{
Pembelajaran IPA Dengan Model Pembelajaran Savi (Somatis Auditori Visual Intelektual) Terhadap Prestasi Belajar Siswa Kelas IV MI NW Dames
}

\author{
Siti Nurul Fitriani \\ Institut Agama Islam Hamzanwadi NW Pancor \\ Email: sitinurulfitriani@iaihnwpancor.ac.id
}

\begin{abstract}
Abstrak
Tujuan dari penelitian ini adalah untuk mengetahui pengaruh penerapan model Pembelajaran SAVI terhadap prestasi belajar IPA siswa MI NW Dames. Populasi dalam penelitian adalah siswa-siswi kelas IV MI NW Dames dan jenis penelitian ini adalah penelitian eksperimen serta pengambilan sampel ditentukan dengan teknik Simple Random Sampling (sampel acak sederhana) yaitu mengacak semua kelas IV yang kemampuannya dianggap setara" dengan hasil kelas $\mathrm{IV}_{\mathrm{A}}$ sebagai kelas eksperimen dan kelas $\mathrm{IV}_{\mathrm{B}}$ sebagai kelas kontrol yang masing-masing berjumlah 22 dan 21 orang.

Penelitian ini termasuk penelitian eksperimen dimana terdapat dua kelompok yaitu kelompok eksperimen dan kelompok kontrol.Teknik pengambilan sampelnya yaitu simple random sampling, dimana dalam pengambilan sampel dipilih secara acak sederhana.Model desain penelitian yang digunakan adalah Posttest-Only Control Design.Teknik pengumpulan data dilakukan dengan teknik tes untuk memperoleh prestasi belajar siswa. Teknik analisis data berupa data kuantitatif.Uji hipotesisnya menggunakan uji-t untuk mencari perbedaan yang signifikan antara kelas eksperimen dan kelas kontrol.

Hasil penelitian diperoleh nilai rata-rata posttest pada kelas eksperimen lebih tinggi dibandingkan kelas kontrol, artinya terdapat peningkatan hasil belajar IPA siswa.Berdasarkan pengujian hipotesis menggunakan rumus t-test independent dapat disimpulkan adaperbedaan yang positif dan signifikan pada model pembelajaran SAVI dan metode demonstrasi terhadap prestasi belajar IPA siswa kelas IV MI NW Dames.
\end{abstract}

Kata Kunci: Model Pembelajaran SAVI IPA Prestasi Belajar. 


\section{PENDAHULUAN}

Kosep IPA atau Ilmu Pengetahuan Alam sebagai konsep pembelajaranalam dan mempunyai hubungan yang sangat luas terkait dengan kehidupan manusia. Selain memberikan bekal ilmu kepada peserta didik, mata pelajaran IPA di tingkat sekolah dasar merupakan wahana untuk menumbuhkan kemampuan berpikir dan memecahkan masalah dalam kehidupan sehari-hari. Mata pelajaran IPA membekali peserta didik pengetahuan, pemahaman dan kemampuan yang berguna untuk memasuki jenjang pendidikan yang lebih tinggi, serta bekal untuk mengembangkan ilmu pengetahuan dan teknologi. ${ }^{1}$

Namun, fakta di lapangan rata-rata pembelajaran IPA yang dilaksanakan di MI NW Dames masih didominasi oleh penggunaan metode ceramah atau metode yang bersifat konvensional yang kegiatannya lebih berpusat pada guru (Teacher Centered). Dalam hal ini tentu saja aktivitas siswa dapat dikatakan hanya mendengarkan penjelasan guru, mencatat hal-hal yang dianggap penting sehingga siswa cenderung dituntut untuk membenarkan apa yang dikatakan oleh guru tanpa usaha untuk membuktikan kebenarannya. Akibatnya siswa bersifat pasif dan guru kurang memberi kesempatan kepada siswa untuk berpikir memcahkan masalah. ${ }^{2}$

Hasil observasi dan wawancara juga menunjukkan proses pembelajaran IPA di MI NW Dames tahun pelajaran 2018/2019 masih belum dapat terlaksana dengan optimal serta hasil belajarnya yang masih rendah di bawah KKM yang telah ditentukan. Untuk itu dibutuhkan suatu pembaharuan dalam pelaksanaan pembelajaran di dalam kelas yaitu dengan menerapkan model pembelajaran yang bisa meningkatkan keaktifan, kreativitas dan konsentrasi siswa dalam belajar.

Salah satu model pembelajaran yang dapat digunakan untuk mengajak siswa aktif bekerjasama dalam memahami dan memecahkan suatu masalah pada mata pelajaran IPA adalah SAVI (Somatic, Auditory, Visual, Intellectual) dimana

1 Leo Sutrisno, dkk. Pengembangan Pembelajaran IPA SD. Jakarta: Dirjen Dikti Depdiknas,2007), hal,31

2 D Meiser, The Accelerated Learning Handbook.Terjemahan oleh Rahmani Astuti. 2002. Bandung: Kaifa.2002),hal,14 
tujuan utama SAVI adalah untuk menggabungkan gerakan fisik dengan aktivitas intelektual serta penggunaan semua indera dalam proses pembelajaran. ${ }^{3}$

Model pembelajaran ini diharapkan dapat membuat suasana belajar menjadi lebih menarik dan menyenangkan karena melibatkan penggunaan semua alat indera yang dimiliki oleh siswa, sehingga pembelajaran pun menjadi lebih komunikatif dan lebih dapat mengoptimalkan potensi-potensi belajar yang dimiliki siswa.

SAVI merupakan kependekan dari Somatic yang bermakna gerakan tubuh (hands-out), aktivitas fisik di mana belajar dengan mengalami dan melakukan; Auditory yang bermakna bahwa belajar haruslah dengan melalui mendengarkan, menyimak, berbicara, presentasi, argumentasi, mengemukakan pendapat, dan menanggapi; Visualization yang bermakna belajar haruslah menggunakan indra mata melalui mengamati, menggambar, mendemonstrasikan, membaca, menggunakan media, dan alat peraga; dan Intellectually yang bermakna bahwa belajar haruslah menggunakan kemampuan berpikir (minds-on) belajar haruslah dengan konsentrasi pikiran dan berlatih menggunakannya melalui bernalar, menyelidiki, mengidentifikasi, menemukan, mencipta, mengonstruksi, memecahkan masalah, dan menerapkan. ${ }^{4}$

Dari penjabaran di atas, peneliti mengajukan rumusan masalah yakni “Apakah ada perbedaan penerapan model pembelajaran SAVI (Somatis Auditori Visual Intelektual) dalam pencapaian prestasi belajar siswa kelas IV MI NW Dames pada pembelajaran IPA?’. Selanjutnya, peneliti menentukan tujuan penelitian, yaitu untuk mengetahui perbedaan penerapan model pembelajaran SAVI dalam pencapaian prestasi belajar siswa kelas IV MI NW Dames pada pembelajaran IPA. Adapun manfaat penelitian ini adalah dapat meningkatkan kualitas pembelajaran di Sekolah Dasar, dapat meningkatkan keaktifan belajar IPA siswa kelas IV MI NW Dames, dan dapat menginspirasi guru dalam melaksanakan proses pembelajaran di kelas.

\footnotetext{
${ }^{3}$ Ibid, hal,91

${ }^{4}$ Ngalimun. Strategi dan Model Pembelajaran. (Banjarmasin: Aswaja Pressindo,2012), hal,166
} 


\section{METODE PENELTIAN}

Penelitian ini termasuk penelitian eksperimen dimana terdapat dua kelompok yaitu kelompok eksperimen dan kelompok kontrol.Teknik pengambilan sampelnya yaitu simple random sampling, dimana dalam pengambilan sampel dipilih secara acak sederhana. Kedua kelompok tersebut peneliti mengasumsikan sama dalam segala segi yang relevan dan hanya berbeda dalam pemberian perlakuan mengajar. Untuk kelas eksperimen diberi perlakuan dengan model pembelajaran SAVI dan untuk kelas kontrol diberi perlakuan dengan metode demonstrasi.

Model desain penelitian yang digunakan adalah Posttest-Only Control Design. ${ }^{5}$ Adapun skemanya seperti di bawah ini.

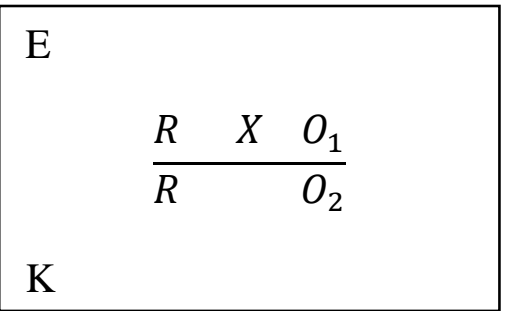

Penelitian ini dilaksanakan di MI NW Dames, Kecamatan Suralaga Kabupaten Lombok Timur Provinsi Nusa Tenggara Barat. Ruang kelas yang diteliti adalah kelas IV tahun pelajaran 2018/2019. Waktu penelitian dilaksanakan mulai dari bulan September sampai dengan bulan Desember 2018 yang terdiri dari tahap persiapan, pelaksanaan, analisis data, dan pelaporan. Subjek penelitiannya adalah guru atau peneliti, sedangkan objek penelitiannya yaitu siswa kelas IV MI NW Dames yang berjumlah 22 orang untuk kelas eksperimen yang terdiri dari 15 siswa laki-laki dan 7 siswa perempuan, sedangkan kelas kontrol berjumlah 21 orang yang terdiri dari 9 siswa laki-laki dan 12 siswa perempuan.

Teknik pengumpulan data menurut adalah teknik atau cara-cara yang dapat digunakan oleh peneliti untuk pengumpulan data. Teknik dalam menunjuk suatu

${ }^{5}$ Sugiyono. 2010. Metode Penelitian Pendidikan Pendekatan Kuantitatif, kualitatif, dan $R \& D$. (Bandung: Alfabeta.2010),hal,76 
kata yang abstrak dan tidak diwujudkan dalam benda, tetapi hanya dapat dilihat penggunaannya melalui angket, wawancara, pengamatan, ujian (tes), dokumentasi, dan lain-lain.Selanjutnya kalau dilihat dari segi cara atau teknik pengumpulan data, maka teknik pengumpulan data dapat dilakukan dengan interview, kuesioner (angket), observasi. ${ }^{6}$

Pemberian tesdalam penelitian ini dimaksudkan untuk mengukur keberhasilan (prestasi) siswa pada ranah kognitif.Instrumen dalam penelitian ini dibedakan menjadi dua yaitu instrumen pelaksanaan pembelajaran dan instrumen untuk pengambilan data.Instrumen pembelajaran berupa silabus, Rencana Pelaksanaan Pembelajaran (RPP), dan Lembar Kegiatan Siswa (LKS).Sedangkan instrumen untuk pengambilan data berupa tes hasil belajar.

Tes hasil belajar ini digunakan untuk mengetahui prestasi belajar siswa terhadap materi pelajaran.Tes yang digunakan adalah tes dalam bentuk pilihan ganda sebanyak 34 butir soal.Berdasarkan uji coba soal yang telah dilakukan diperoleh 17 soal yang valid. Soal yang valid ini nantinya akan digunakan sebagai alat untuk mengambil data pada tempat penelitian. Skor 1 untuk yang menjawab benar dan skor 0 untuk yang menjawab salah.

Analisis data dilakukan untuk mengetahui kebenaran hipotesis yang diajukan. Teknik analisis data dilakukan dengan melakukan uji prasyarat analisis sebagai berikut:

a) Uji Normalitas

Untuk mengetahui apakah sampel berasal dari populasi yang berdistribusi normal digunakan uji normalitas dengan Chi-Kuadrat, yaitu :

$X^{2}=\sum_{i=1}^{k} \frac{\left(f_{0}-f_{h}\right)^{2}}{f_{h}}$

Keterangan:

$X^{2}=$ Harga Chi-Kuadrat

$f_{o}=$ Frekuensi yang ada (frekuensi observasi atau frekuensi sesuai dengan keadaan)

${ }^{6}$ Ibid, hal, 193 
$f_{h}=$ Frekuensi yang diharapkan, sesuai dengan teori. ${ }^{7}$

b) Uji Homogenitas

Dilakukan untuk mengetahui apakah kedua data yang digunakan dalam penelitian ini homogen atau tidak homogen. Salah satu teknik statistik yang digunakan untuk menjelaskan homogenitas kelompok adalah dengan varians.Varians merupakan jumlah kuadrat semua deviasi nilai-nilai individual terhadap rata-rata kelompok. Varians untuk sampel disimbolkan dengan $S^{2}$ dan standar deviasi sampel diberi simbol $S$. Pengujian homogenitas menggunakan uji-F dengan rumus sebagai berikut:

$$
\begin{aligned}
& F=\frac{S_{1}^{2}}{S_{2}^{2}}(2) \\
& F_{\text {hitung }}=\frac{\text { varian terbesar }}{\text { varian terkecil }}
\end{aligned}
$$

Keterangan :

$F=$ Koefisien Hitung $\left(F_{\text {hitung }}\right)$

$S_{1}^{2}=$ Varians Terbesar

$S_{2}^{2}=$ Varians Terkecil

Dengan hipotesis:

Ho : varians data tidak homogen

Ha : varians data homogeny

Sebelum kita menghitung nilai $\mathrm{F}$, terlebih dahulu kita mencari nilai varians terbesar dan varians terkecil dengan rumus:

$$
S^{2}=\frac{\sum\left(x_{i}-\bar{x}\right)^{2(3)}}{n-1}
$$

${ }^{7}$ Ibid, hal, 107 
2. Syarat agar varians bersifat homogeny apabila nilai $\mathrm{F}$ hitung lebih kecil dari $\mathrm{F}$ tabel dan nilai antara $\mathrm{f}$ signifikansi hitung lebih besar daripada nilai taraf signifikansi $\alpha=0,05$.

c. Pengujian Hipotesis

a) Asumsi

1. Populasi-populasi berdistribusi normal

2. Populasi-populasi homogen

3. Sampel dipilih secara acak

b) Hipotesis

$H_{o}$ : Pembelajaran IPA menggunakan model pembelajaran SAVI kurang efektif dibandingkan dengan metode demonstrasi terhadap prestasi belajar siswa pada pokok bahasan energi bunyi di kelas IV MI NW Dames Tahun Pelajaran 2018/2019.

$H_{a}$ : Pembelajaran IPA menggunakan model pembelajaran SAVIlebih efektif dibandingkan dengan metode demonstrasi terhadap prestasi belajar siswa pada pokok bahasan energi bunyi di kelas IV MI NW Dames Tahun Pelajaran 2018/2019.

c) Komputasi

Pengujian hipotesis dalam penelitian ini menggunakan uji-t, dengan rumus sebagai berikut.

$$
t=\frac{\bar{X}_{1}-\bar{X}_{2}}{\sqrt{\frac{\left(n_{1}-1\right) s_{1}^{2}+\left(n_{2}-1\right) s_{2}^{2}}{n_{1}+n_{2}-2}\left(\frac{1}{n_{1}}+\frac{1}{n_{2}}\right)}}
$$

Keterangan:

$\mathrm{t}=$ Nilai $\mathrm{t}$ yang dihitung

$\bar{X}=$ Nilai rata-rata

$\mathrm{s}=$ Simpangan baku sampel 
$\mathrm{n}=$ Jumlah anggota sampel. ${ }^{8}$

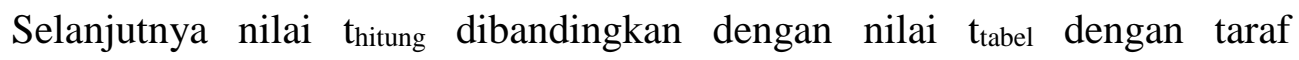
kepercayaan 95\%. Jika $t_{\text {hitung }}<t_{\text {tabel }}$ maka $\mathrm{H}_{0}$ diterima, sedangkan jika $t_{\text {hitung }}>t_{\text {tabel }}$ maka $\mathrm{H}_{0}$ ditolak.

\section{HASIL PENELITIAN DAN PEMBAHASAN}

\section{A. Hasil Penelitian}

Sebelum mengadakan penelitian, peneliti terlebih dahulu mengadakan pretest yang bertujuan untuk mengetahui kemampuan awal siswa. Dari hasil pretest pada kelas $\mathrm{IV}_{\mathrm{A}}$ (Kelas Eksperimen) diperoleh nilai rata-rata 54,59 sedangkan pada kelas $\mathrm{IV}_{\mathrm{B}}$ (Kelas Kontrol) diperoleh nilai rata-rata 53,52.

Setelah semua rangkaian kegiatan pembelajaran dilaksanakan, kemudian pada pertemuan terakhir peneliti melaksanakan posttest masing-masing kelas $\mathrm{IV}_{\mathrm{A}}$ sebagai kelas eksperimen dengan jumlah siswa 22 orang dan pada siswa kelas IV $_{B}$ sebagai kelas kontrol dengan jumlah siswa 21 orang.Untuk lebih jelasnya dapat dilihat pada tabel 1 .

Tabel 1.

Nilai Pretest dan Posttest Kelas Eksperimen dan Kelas Kontrol

\begin{tabular}{|l|c|c|c|c|}
\hline \multirow{2}{*}{\multicolumn{1}{|c|}{ Data }} & \multicolumn{2}{c|}{ Eksperimen } & \multicolumn{2}{c|}{ Kontrol } \\
\cline { 2 - 5 } & Pretest & Posttest & Pretest & Posttest \\
\hline Jumlah Siswa & 22 & 22 & 21 & 21 \\
\hline Nilai rata-rata kelas & 54,55 & 78,70 & 53,55 & 70,95 \\
\hline Nilai tertinggi & 76 & 94 & 76 & 88 \\
\hline Nilai terendah & 35 & 65 & 35 & 59 \\
\hline Jumlah Siswa Tuntas & 5 & 20 & 6 & 12 \\
\hline Jumlah siswa tidak tuntas & 15 & 4 & 17 & 7 \\
\hline KKM & 70 & 70 & 70 & 70 \\
\hline
\end{tabular}

Dari tabel 1 menunjukkan bahwa untuk kelas eksperimen nilai rata-rata pretest 54,55 dengan nilai tertinggi 76 dan nilai terendah 35, untuk nilai rata-rata posttest 78,70 dengan nilai tertinggi 94 dan nilai terendah 65. Sedangkan untuk kelas kontrol nilai rata-rata pretest 53,55 dengan nilai tertinggi 76 dan nilai terendah 35 , untuk niai rata-rata posttest 70,95 dengan nilai tertinggi 88 dan nilai terendah 59 .

\footnotetext{
${ }^{8}$ Ibid, hal. 99
} 
Hasil penelitian untuk kelas eksperimen dan kelas kontrol juga dapat disajikan dalam bentuk tabel distribusi frekuensi.Adapun tabel distribusi frekuensi posttest kelas eksperimen dan kelas kontrol disajikan pada tabel 2.

\section{Tabel 2.}

Distribusi Frekuensi Nilai Posttest Kelas Eksperimen

\begin{tabular}{|c|c|c|}
\hline Interval Nilai & Titik Tengah & Frekuensi \\
\hline $65-70$ & 67,5 & 1 \\
\hline $71-76$ & 73,5 & 12 \\
\hline $77-82$ & 79,5 & 4 \\
\hline $83-88$ & 85,5 & 3 \\
\hline $89-94$ & 91,5 & 2 \\
\hline \multicolumn{2}{|c|}{ Jumlah } \\
\hline
\end{tabular}

(Sumber: data primer yang diolah peneliti)

Dari tabel 2 terlihat bahwa frekuensi terbesar terletak pada titik tengah 73,5. Hal ini menunjukkan bahwa siswa lebih banyak memperoleh nilai pada interval 71-76. Untuk mendukung pernyataan ini bisa dilihat pada histogram (Gambar 1) di bawah ini:

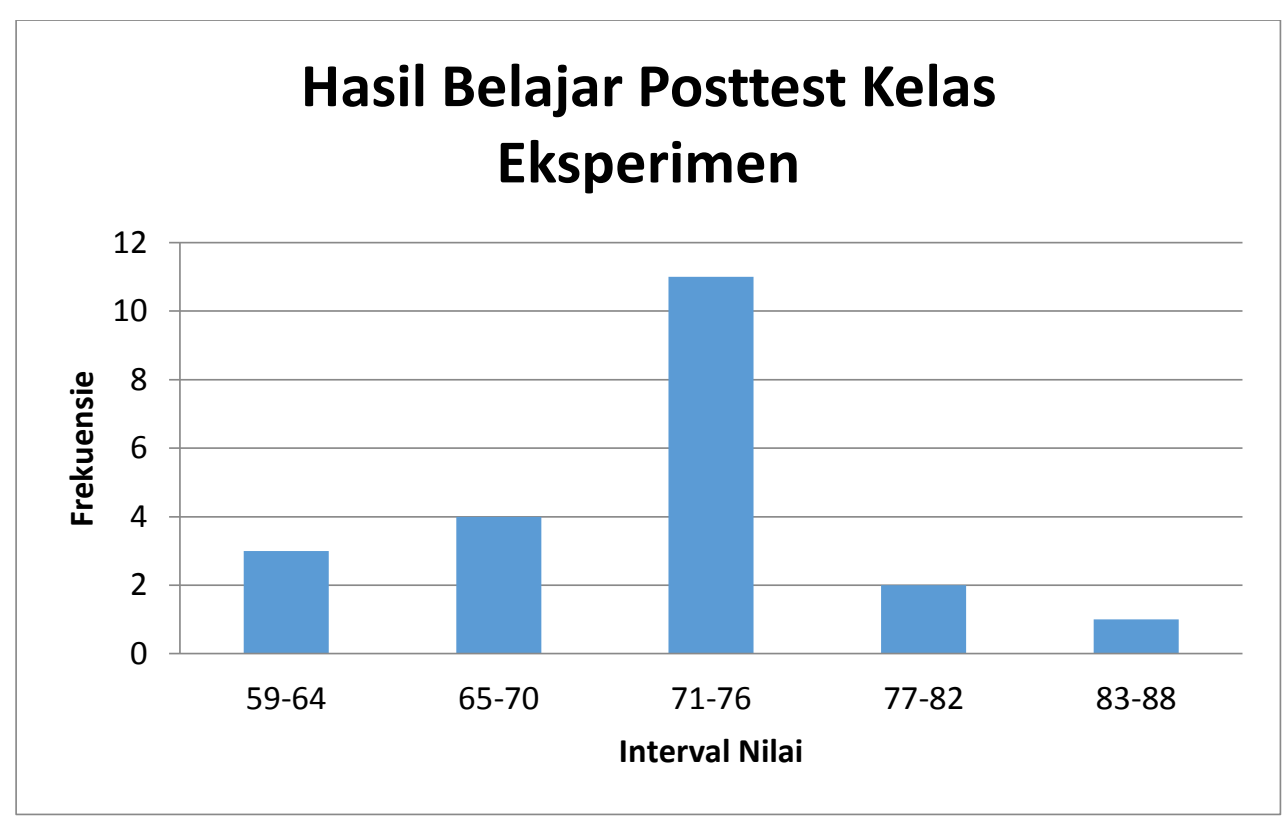

Gambar 1. Hasil belajar posttest kelas eksperimen 
Tabel distribusi frekuensi nilai posttest kelas kontrol disajikan pada tabel 3.

Tabel 3.

Distribusi Frekuensi Nilai Posttest Kelas Eksperimen

\begin{tabular}{|c|c|c|}
\hline Interval Nilai & Titik Tengah & Frekuensi \\
\hline $59-64$ & 61,5 & 3 \\
\hline $65-70$ & 67,5 & 4 \\
\hline $71-76$ & 73,5 & 11 \\
\hline $77-82$ & 79,5 & 2 \\
\hline $83-88$ & 85,5 & 1 \\
\hline \multicolumn{2}{|c|}{ Jumlah } \\
\hline
\end{tabular}

(Sumber: data primer yang diolah peneliti)

Dari tabel di atas terlihat bahwa frekuensi terbesar berada pada nilai tengah 73,5 yang menunjukkan siswa paling banyak memperoleh nilai pada interval 71-76. Hal ini dapat dipertega dengan diagram batang pada gambar 2 .

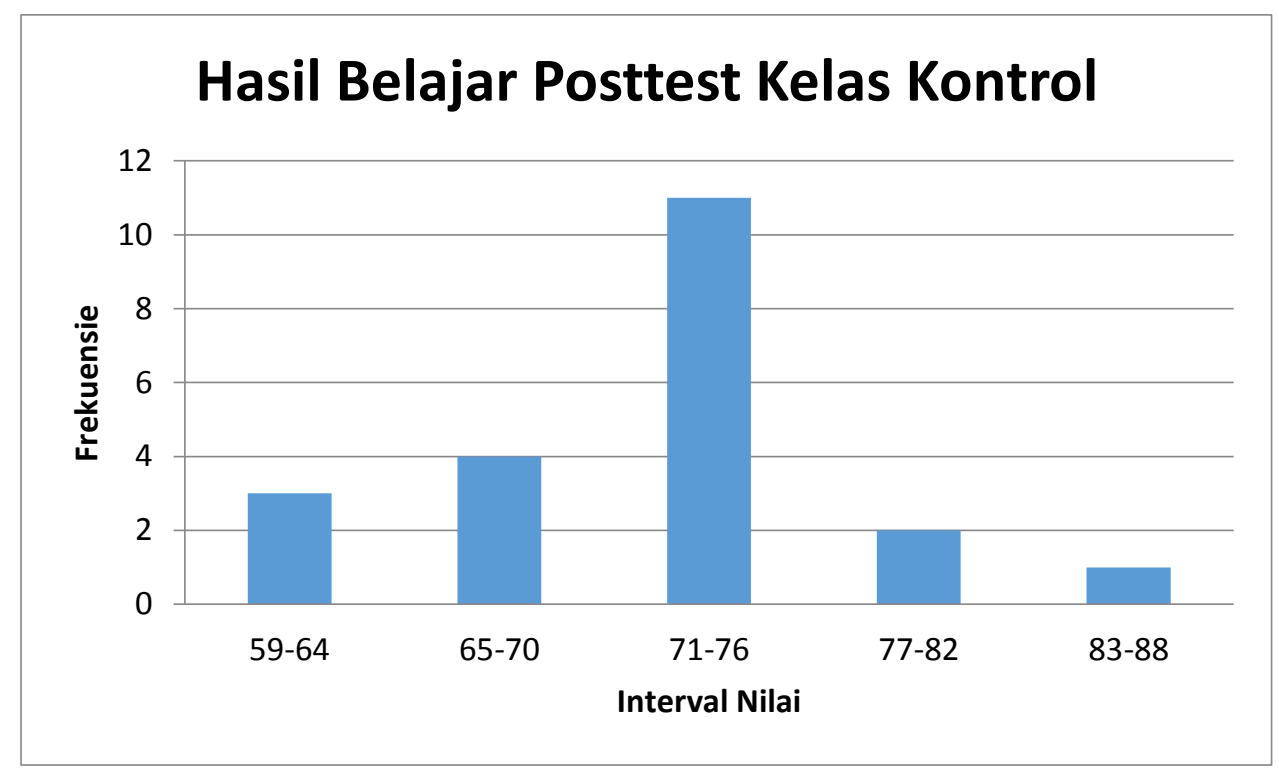

Gambar 2. Hasil Belajar Posttest Kelas Kontrol

Uji normalitas data dilakukan untuk menguji apakah data dari variabelvariabel yang diteliti mendekati distribusi normal atau tidak. Variabel yang diuji normalitas datanya adalah data hasil tes pemahaman siswa pada pokok bahasan energi bunyi. Untuk menganalisis data tersebut digunakan uji chi-khuadrat, dengan ketentuan $X^{2}$ hitung $<X^{2} t_{a b e l}$ maka distribusi data dikatakan normal, dan sebaliknya jika $X^{2}{ }_{\text {hitung }}>X^{2} t_{\text {abel }}$ maka distribusi data dikatakan tidak normal. Hasil perhitungan uji normalitas data dapat dilihat pada tabel 3. 
Tabel 3.

Uji Normalitas

\begin{tabular}{|c|c|c|c|c|c|}
\hline No. & $\begin{array}{c}\text { Hasil } \\
\text { Belajar }\end{array}$ & Kelas & $\boldsymbol{X}^{2}$ hitung & $\boldsymbol{X}^{2} \boldsymbol{t}_{\text {abel }}$ & Keterangan \\
\hline 1 & \multirow{2}{*}{ Posttest } & Eksperimen & $-8,84$ & 9,488 & Normal \\
\cline { 3 - 6 } & & Kontrol & $-7,04$ & 9,488 & Normal \\
\hline
\end{tabular}

Dari tabel di atas untuk kelompok atau kelas eksperimen menunjukkan bahwa harga $\chi^{2}$ hitung adalah 8,44 sementaraharga kritik $\chi^{2}$ tabel adalah 9,488 karena $\chi_{\text {tabel }}^{2}>\chi^{2}$ hitung maka dapat disimpulkan sampel berasal dari populasi yang berdistribusi normal sedangkan untuk kelompok atau kelas kontrol harga $\chi^{2}$ hitungadalah7,04sementara harga kritik $\chi_{\text {tabel }}^{2}$ adalah 9,48 karena $\chi^{2}{ }_{\text {tabel }}>\chi^{2}$ hitung maka dapat disimpulkan sampel berasal dari populasi yang berdistribusi normal

Selanjutnya uji homogenitas digunakan untuk menentukan data homogen atau tidak diambil dari hasil posttest. Uji statistik yang digunakan dalam penelitian ini adalah uj F. Berikut disajikan rangkuman perhitungan dengan menggunakan Uji F.

Tabel 4.

Uji Homogenitas

\begin{tabular}{|c|c|c|c|c|c|c|c|c|}
\hline No. & $\begin{array}{c}\text { Hasil } \\
\text { Belajar }\end{array}$ & Kelas & $\mathbf{d k = n - 1}$ & $\mathbf{X}$ & $\mathbf{S}^{\mathbf{2}}$ & $\mathbf{F}_{\text {hitung }}$ & $\mathbf{F}_{\text {tabel }}$ & Keterangan \\
\hline 1 & \multirow{2}{*}{ Posttest } & Eksperimen & $22-1$ & 78,73 & 87,60 & 1,074 & 2,11 & Homogen \\
\cline { 3 - 9 } & & Kontrol & $21-1$ & 70,95 & 81,54 & 1,074 & 2,11 & Homogen \\
\hline
\end{tabular}

Berdasarkan tabel4 diatas diperoleh bahwa harga $\mathrm{F}_{\text {hitung }}$ sebesar 1,074 sementara harga $\mathrm{F}_{\text {tabel }}$ untuk derajat kebebasan pembilang 21 dan derajat kebebasan penyebut 20 dalam taraf signifikan 5\% sebesar 2.11. Berdasarkan kriteria yang ada yaitu apabila $\mathrm{F}_{\text {hitung }}<\mathrm{F}_{\text {tabel }}$ maka kedua kelompok tersebut berasal dari sampel homogen.

Setelah terpenuhi persyaratan analisis tersebut, maka dapat dilakukan uji hipotesis guna memenuhi apakah hipotesis yang telah diajukan diterima atau ditolak. Rumus yang digunakan untuk menguji hipotesis adalah dengan uji-t dengan $t_{\text {tabel }}$ pada taraf signifikan $5 \%(0,05)$. 
Berikut akan disajikan rangkuman hasil perhitungan data prestasi belajar antara kelompok siswa yang diajar dengan menggunakan model pembelajaran SAVI dengan kelompok siswa yang diajar dengan menggunakan metode demonsrasi seperti ditunjukkan dalam tabel 5 di bawah ini:

Tabel 5.

Rangkuman Hasil Uji Hipotesis (Uji-t) Data Prestasi Belajar Siswa

\begin{tabular}{|c|l|c|c|c|c|c|}
\hline No & \multicolumn{1}{|c|}{ Kelas } & $\boldsymbol{n}$ (Sampel) & $\bar{x}$ & $\boldsymbol{S}^{\mathbf{2}}$ & $\mathbf{t}_{\text {hitung }}$ & $\mathbf{t}_{\text {tabel }}$ \\
\hline 1 & Eksperimen & 22 & 70,25 & 169,67 & \multirow{2}{*}{2,99} & \multirow{2}{*}{2,02} \\
\hline 2 & Kontrol & 21 & 56,75 & 240,20 & & \\
\hline
\end{tabular}

Untuk mengetahui apakah model pembelajaran SAVIlebih efektif terhadap prestasi belajar IPA pokok bahasan energi bunyi, maka dilakukan pengujian hipotesis dengan menggunakan uji-t. Setelah dihitung didapatkan $t_{\text {hitung }}=2,99$. Sementara itu harga t pada taraf signifikansi $5 \%(0,05) \mathrm{dk}=41$ ditetapkan sebesar 2,02. Dengan demikian, $t_{\text {hitung }}>\mathrm{t}_{\text {tabel }}$ yaitu $2,99>2,02$, sehingga dapat dinyatakan kalau hipotesis alternatif diterima.

\section{B. Pembahasan}

Berdasarkan analisis hasil penelitian, kita ketahui bahwa prestasi belajar kelompok eksperimen lebih baik dari prestasi belajar kelompok kontrol.Hal ini disebabkan karena kedua kelompok diberikan perlakuan yang berbeda.Pada kelompok eksperimen dengan menggunakan model pembelajaran SAVI, sedangkan pada kelompok kontrol menggunakan pembelajaran dengan metode demonstrasi.

Adapun pada saat melakukan penelitian dengan model pembelajaranSAVIdi kelas eksperimen, terlihat bahwa siswanya tertarik dan ikut aktif berpartsifasi dalam proses belajar mengajar. Interaksi antarsiswa dengan siswa ataupun antar siswa dengan guru berjalan baik. Respon siswa terhadap materi pelajaran sangat 
baik, kerjasama antarkelompok berjalan lancar. Mereka tampak senang dengan metode yang digunakan, karena mereka diberikan kesempatan untuk dapat membantu satu sama lain dan belajar menggunakan semua indra.

Hal ini sesuai dengan penelitian yang dilakukan oleh Hasanah tahun 2015 yang berjudul "Penerapan Model Pembelajaran SAVI (Somatis Auditori Visual Intelektual) untuk Meningkatkan Keaktifan Belajar Siswa dalam Pembelajaran IPA SD Negeri 1 Lebengjumuk Tahun Pelajaran 2015/2016”. Hasil penelitiannya menunjukkan bahwa Model Pembelajaran SAVI (Somatis Auditori Visual Intelektual) dapat meningkatkan keaktifan belajar siswa dalam pembelajaran IPA kelas III SD Negeri 1 Lebengjumuk tahun 2015/ 2016.

Hasil Post-Test kelas eksperimen lebih tinggi di banding kelas kontrol disebabkan tidak lepas dari kelebihan-kelebihan penerapan model pembelajaran SAVI Shoimin (2014: 182) yaitu antara lain sebagai berikut: (1) meningkatkan kecerdasan secara terpadu siswa secara penuh melalui penggabungan gerak fisik dengan aktivitas intelektual; (2) ingatan siswa terhadap materi yang dipelajari lebih kuat, karena siswa membangun sendiri pengetahuannya; (3) Suasana dalam pembelajaran menjadi menyenangkan karena siswa merasa diperhatikan sehingga tidak bosan dalam belajar; (4) Memupuk kerja sama, dan diharapkan siswa yang lebih pandai dapat membantu siswa lain yang kurang pandai; (5) Menciptakan suasana belajar yang lebih menarik dan efektif; (6) Mampu meningkatkan kreativitas dan kemampuan psikomotor siswa; (7) Memaksimalkan konsentrasi siswa; (8) Siswa akan termotivasi untuk belajar lebih giat; dan (9) Melatih siswa untuk terbiasa berfikir dan mengemukakan pendapat dan berani menjelaskan jawabannya.

Dari beberapa kelebihan tersebut teori belajar yang diungkapkan oleh Jean Piaget, yang memaknakan bahwa proses belajar berawal dari pengalaman siswa sendiri, sangat dominan pada penerapan model pembelajaran SAVI ini. Siswa yang belajar secara individu tentunya akan memberikan peranan penting dalam pemecahan suatu masalah, baik dari segi pengetahuan maupun pengalaman. Itulah sebabnya, penggunaan model pembelajaran SAVI tidak lepas dari peranan siswa secara individu, tetapi dikombinasikan secara lebih umum melalui pembentukan 
kelompok-kelompok, sebagai ajang kerja sama yang mencerminkan siswa dalam kehidupan sosialnya. Sehingga hasilnya dapat memberikan dampak yang positif terhadap prestasi belajar siswa.

Berpendapat bahwa dengan memperhatikan konsep belajar SAVI, siswa mempunyai kesempatan untuk berperan aktif dalam proses belajar mengajar sehingga dengan menggunakan model pembelajaran SAVI dapat meningkatkan hasil belajar siswa. Penggunaan model pembelajaran SAVI akanmemberikan hasil belajar yang lebihbaik karena terjadi interaksi tatap muka dalam anggota kelompok dan kemampuan menjalin hubungan interpersonal. Dengan adanya model pembelajaran ini, guru melatih siswa untuk bertanggung jawab untuk menyelesaikan tugasnya dan mengembangkan hubungan interpersonal serta menumbuhkan kepercayaan diri siswa. ${ }^{9}$

Dari hasil evaluasi pada materi kalor pada siswa kelas eksperimen dan kelas kontrol.Dapat dilihat bahwa ada perbedaan hasil evaluasi antara kelas eksperimen dan kelas kontrol.Sehingga dapat dikatakan bahwa penggunaan model pembelajaran SAVI efektif terhadap prestasi belajar IPA pokok bahasan energi bunyi siswa kelas IV MI NW Dames Tahu Pelajaran 2018/2019.

${ }^{9}$ Adang Suherman. Penelitian Korelasional dan Komparasi dalam Kurikulum dan Pengajaran. (Program Pascasarjana UPI: Bandung.2002),hal,52 


\section{KESIMPULAN}

Berdasarkan hasil penelitian dan pembahasan hasil penelitian ini, maka dapat ditarik kesimpulan bahwa Secara signifikansi prestasi belajar IPA siswa yang diajar dengan menggunakan model pembelajaran SAVI (Somatis Auditori Visual Intelektual) berbeda dengan prestasi belajar IPA siswa yang diajar dengan menggunakan metode demonstrasi.

Prestasi belajar IPA siswa yang diajar dengan menggunakan model pembelajaran SAVI berada pada kualifikasi yang cukup sedangkan prestasi belajar IPA siswa yang diajar dengan menggunakan metode demonstrasi berada pada kualifikasi kurang.Ini menunjukkan bahwa prestasi belajar IPA yang dicapai oleh siswa yang diajar dengan menggunakan model pembelajaran SAVI secara signifikan lebih efektif daripada prestasi belajar IPA yang dicapai oleh siswa yang diajar dengan menggunakan metode demonstrasi. 


\section{DAFTAR PUSTAKA}

Adang, Suherman. Penelitian Korelasional dan Komparasi dalam Kurikulum dan Pengajaran. Program Pascasarjana UPI: Bandung.2002

Hasanah. Penerapan Model Pembelajaran SAVI (Somatis Auditori Visual Intelektual) untuk Meningkatkan Keaktifan Belajar Siswa dalam Pembelajaran IPA SD Negeri 1 Lebengjumuk Tahun Pelajaran 2015/2016. Skripsi tidak dipublikasikan, Universitas Muhammadiyah Surakarta. 2015

Leo Sutrisno, dkk. Pengembangan Pembelajaran IPA SD. Jakarta: Dirjen Dikti Depdiknas. 2007

D Meir, The Accelerated Learning Handbook.Terjemahan oleh Rahmani Astuti. 2002. Bandung: Kaifa.2002

Ngalimun. 2012. Strategi dan Model Pembelajaran. Banjarmasin: Aswaja Pressindo.2012

Aris Shoimin, Model Pembelajaran Inovatif dalam Kurikulum 2013. Yogyakarta: Ar-Ruzz Media.2014

Sugiyono. . Metode Penelitian Pendidikan Pendekatan Kuantitatif, kualitatif, dan R\&D. Bandung: Alfabeta.2010

.Metode Penelitian Kuantitatif Kualitatif dan R\&D. Bandung: Alfabeta.2012 